Saudi Journal of Biomedical Research

Abbreviated Key Title: Saudi J Biomed Res ISSN 2518-3214 (Print) |ISSN 2518-3222 (Online)

\title{
Evaluation of the Antiproliferative and Free Radical Scavenging Potentials of the Saponin-Containing Chromatography Fractions of Olax viridis (Olacaeceae) Root Bark
}

Azumara, Uchechukwu Victor ${ }^{1}$, Okonkwo, Tochukwu Josiah Nnaemeka ${ }^{1}$, Okonkwo, Onyinye Blessing ${ }^{2,3}$, Afieroho, Ozadheoghene Eriarie $^{2^{*}}$

\begin{abstract}
${ }^{1}$ Department of Pharmaceutical and Medicinal Chemistry, Faculty of Pharmaceutical Sciences, University of Port Harcourt, Port Harcourt, Nigeria ${ }^{2}$ Department of Pharmacognosy and Phytotherapy, Faculty of Pharmaceutical Sciences, University of Port Harcourt, Port Harcourt, Nigeria

${ }^{3}$ Department of Pharmacognosy, Faculty of Pharmaceutical Sciences, Chukwuemeka Odumegwu Ojukwu University, Igbariam Campus, Anambra State, Nigeria
\end{abstract}

DOI: $10.36348 /$ sjbr.2020.v05i04.008

| Received: 10.04.2020 | Accepted: 18.04.2020 | Published: 24.04.2020

*Corresponding author: Afieroho, Ozadheoghene Eriarie

\section{Abstract}

Olax viridis Oliv. (Olacaceae) is a shrub common in the tropics and grows well in the forest and savannah region. Species of this genus are used traditionally in the treatment of breast cancer and related diseases among others. This study aims to report the antiproliferative and in vitro antioxidant activities of butanol fraction of $O$. viridis root bark. Extraction of the pulverized dry bark was done by cold maceration using methanol and was further partitioned successively with $\mathrm{N}$ hexane, dichloromethane, ethyl acetate and n-butanol. Fractionation of butanol fraction was done with vacuum-liquidchromatography and subfractions monitored with TLC. Phytochemical screening of fraction A-C was carried out using standard phytochemical method while their constituents were evaluated using TLC. Antiproliferative activity was determined by cell viability assay using Saccharomyces cerevisae (yeast) as a model organism while the 2,2-diphenyl-1picrylhydrazyl (DPPH) radical scavenging assay was used for antioxidant evaluation in-vitro with ascorbic acid as the reference standard for comparison. All the sub-fractions contain sugar, steroids, triterpenes and saponins. Sub-fractions A, B and C showed constituents $\left(R_{f}\right.$ values of $0.23,0.41,0.51$ and 0.58$),\left(R_{f}\right.$ values of 0.46 and 0.63$)$ and $\left(R_{f}\right.$ values of 0.44 and 0.62 ) respectively. The sub-fraction A showed dose-dependent activities for DPPH radical scavenging activity thus $\mathrm{A}\left(\mathrm{IC}_{50}=1.60 \mathrm{mg} / \mathrm{ml}\right)$ while antiproliferative activities of all the sub-fractions were dose dependent $\mathrm{A}\left(\mathrm{IC}_{50}=8.22 \mathrm{mg} / \mathrm{ml}\right)>\mathrm{B}\left(\mathrm{IC}_{50}=>10 \mathrm{mg} / \mathrm{ml}\right)$. Sub fraction A showed a promising activity, and this preliminary study validated the traditional use of Olax species in the treatment of cancer.

Keywords: Olax viridis, saponins, anti-proliferative, free radical scavenging, drug discovery and development.

Copyright @ 2020: This is an open-access article distributed under the terms of the Creative Commons Attribution license which permits unrestricted use, distribution, and reproduction in any medium for non-commercial use (NonCommercial, or CC-BY-NC) provided the original author and source are credited.

\section{INTRODUCTION}

The pathophysiology of cancers has long been linked to the presence of free radicals. Few years ago, cancer was seen to be a disease of Western world, but that is no longer the case. It is now a growing noncommunicable disease all over the world. In a 2018 global report, cancer was responsible for 9.6 million deaths translating to nearly 1 in 6 of all global deaths [1].The low and middle-income countries of the world have been reported to account for about $70 \%$ of these deaths [1]. In Africa, cancer is an emerging public health disease of utmost concern. About 715,000 new cancer cases and 542,000 cancer deaths occurred in 2008 in the continent, with these numbers expected to double in the next 20 years [2]. The continue increase in the number of cancer incidence all over the world to a great extent is due to life style and to a lesser extent genetically. Mortality due to this disease is attributed to late diagnosis, ignorance and most of all resistance to the existing drugs or non-responsiveness to treatment. These assertions should awaken researchers in the field of drug discovery and development to dive into studies and discoveries of new drugs or lead compound in other to avert a looming pandemic. Also the amount of money that is spent on cancer chemotherapy is a source of worry to cancer patients, government, agencies, and non-governmental organization. Therefore, any source of effective and cheaper treatment for cancer will be easily accepted by the populace. More so, the serious adverse effect associated with the available cancer chemotherapeutic drugs that worsen the patient's quality of life such as alopecia (loss of hairs), bone marrow depression, immunosuppression, 
leucocytopenia etc., are of great concern. Medicinal plants will continue to provide a source for generating novel drug compounds. Plants may become the base for the development of a new medicine or they may be used as phytomedicine for the treatment of diseases [3]. The primary benefit of using plant-derived medicine is that they are relatively safer than synthetic alternatives, offering profound therapeutic benefits and more affordable treatments. Plant products have always proven to have the potential of providing solution to majority of health related problem of man, and cancer is not an exception. A school of thought believe that the lasting solution to cancer treatment lies within the leaves, stems, trunks, roots, fruits, rhizomes of our God given plants. The extraction of bioactive agent from plants is of the most intensive areas of natural product research today, yet the field is far from being exhausted [4]. Bioactives of natural source are too vast, and in these bioactives lay solutions to man's health challenges. However only few of these plants have been investigated for their physiological activities. Screening of plant bioactive agents prove that the isolates from the plant elicit certain physiological and pharmacological properties, attributed to the plants ethno medicinal uses. Olax viridis Oliv. (Olacaeceae Juss), is a plant that has been known to be use by its indigenous populace for several ailment with most of its widely claimed activities due to its antimicrobial properties. In some case liver diseases has been claimed to have been treated with part of this plant. No claim either traditionally or scientifically has been made regarding its anticancer properties; however there is a claim of the use of one of the species of the Olax genus specifically, $O$. subscorpioidea root in the management of breast cancer in Abeokuta, Ogun State in Nigeria [5-6]. This specie bears the same native name as $O$. viridis amongst the Igbo ethnic group. Also a report on the traditional use of the alcoholic extract of the aerial parts, a member of the family Olacaeceae (Jasminum grandiflorum), traditionally in the treatment of various tumors and cancer, have been documented [7]. Oleic acid isolated from $O$. europea have been demonstrated to possess anticancer activity [8]. A few plant bioactive compounds have found useful and are the main stay in the management of cancer in our contemporary society and more are still in different stages of research of which some are saponins [8-10]. There is a chance that better bio active compounds still exist in plants yet to be investigated for anti-cancer properties.

\section{MATERIALS AND METHODS}

\section{Plant Sample Collection and Preparation of Extract}

The root of the plant $O$. viridis, was obtained by uprooting and cutting out the root. The roots were collected from farmlands in Nsukka South Eastern Nigeria and authenticated by taxonomist $\mathrm{Mr}$ A.O Ozioko of the Bio-resources Conservation and Development Program (BDCP), Nsukka, Nigeria The bark was peeled off the root, washed off of earth material and dried at an ambient temperature. The dried sample was pulverized to fine powdered sample. Extraction was done by cold maceration. A $1000 \mathrm{~g}$ of the powdered sample was macerated in methanol $(10 \mathrm{~L})$ at room temperature in a glass bottle with intermittent agitation using magnetic stirrer for 72 hours. The mixture was then filtered using the vacuum pump and Buchner funnel. The filtrate was partitioned in a separating funnel using n-hexane, dichloromethane, ethyl acetate, n-butanol and water in their order of polarity to obtain their fractions. The saponin containing n-butanol fraction was used for this study.

\section{Separation of n-butanol Fraction with Vacuum Liquid Chromatography}

The n-butanol fraction was subjected to silica gel vacuum liquid chromatography (VLC) to obtain a pure sample. Briefly, a 60-120 mesh size silica gel was packed in a column until it became compact. The nbutanol fraction was adsorbed on small amount of silica gel and added to the column. N-hexane, dichloromethane and methanol were used as a mobile phase, while applying a negative pressure. Five different fractions were eluted; fractions 1,2,3,4 and 5 . Fractions 3, 4 and 5 which gave a positive test for saponins were coded sub-fraction A, B and C and were investigated further in this study.

\section{Phytochemical screening}

These sub-fractions were screened for phytoconstituents following standard phytochemical screening method $[11,12]$.

\section{Antiproliferative assay}

Anti-proliferative assay was carried out using the Saccharomyces cerevisiae (yeast) model [13]. A $20 \mathrm{ml}$ sabouraud dextrose broth (SDB) was prepared by dissolving $0.6 \mathrm{~g}$ of powder nutrient broth in distilled water $(20 \mathrm{~mL})$ and sterilized in an autoclave at a pressure of $121 \mathrm{psi}$ for 15 minutes. The broth was cooled and aseptically inoculated with $S$. Cerevisiae. The above mixture was incubated for 24 hours at $37^{\circ} \mathrm{C}$. This was known as seeded broth. One loop full of the seeded broth was aseptically transferred into $10 \mathrm{ml}$ peptone water, incubated for 24 hours at a temperature of $37^{\circ} \mathrm{C}$ and further diluted to a 0.1 Mac Farland standard, this served as the standardized inoculum. A $10 \mathrm{mg} / \mathrm{ml}$, $1 \mathrm{mg} / \mathrm{ml}, 0.1 \mathrm{mg} / \mathrm{ml}$ concentrations each of fractions A-C were prepared aseptically. For each fraction, $1 \mathrm{ml}$ each of the above concentrations was transferred into sterilized $2.5 \mathrm{ml} \mathrm{SDB}$, which were then inoculated with $0.1 \mathrm{ml}$ of the standardized inoculums. A negative control containing the SDB and $0.1 \mathrm{ml}$ of the yeast inoculum only was prepared alongside the standard anticancer drug - methotrexate $(1000 \mu \mathrm{g} / \mathrm{ml}, 100 \mu \mathrm{g} / \mathrm{ml}$ and 10 $\mu \mathrm{g} / \mathrm{ml})$ Each of these were prepared in duplicates and incubated at $37^{\circ} \mathrm{C}$ for 24 hours. The whole procedure above was carried out aseptically to avoid contamination. $0.1 \mathrm{ml}$ each of the broth were then stained with $0.1 \mathrm{ml}$ of $0.1 \%$ methylene blue and were charge under the hemocytometer and viewed under the microscope with ocular lens of $\times 100$ magnification. The 
number of viable cells and non-viable cells were determined for each of the concentrations and the Percentage non-viable $=\underline{\text { Total number of non-viable cells }} \times 100$

Total number of cells

Free radical scavenging (Antioxidant) assay

A quantitative diphenyl-1-picrylhydrazyl (DPPH) antioxidant assay was carried out on 2.0, 1.5, $1.0 \mathrm{mg} / \mathrm{ml}$ concentrations each of the 3 fractions using methanol as reported [14, 15] with modification. Briefly, the various concentrations were mixed with a freshly prepared methanol solution of (DPPH) in a test tube wrapped with a foil to prevent exposure to light, at percentage death of the cells determined with the following formula;

Inhibition of DPPH radical $(\%)=100 x\left[\frac{\left[A_{(\text {egative control })}-A_{(\text {sample })}\right]}{A_{(\text {negative control })}}\right.$

Where: $\underline{A}_{(\text {negative control })}=$ Absorbance of the negative control solution (containing all the reagents except the test extract)

$$
\underline{A}_{(\text {sample })} \perp=\text { Absorbance of the test extract. }
$$

The $\mathrm{IC}_{50}$ was obtained by extrapolation from the regression curve

\section{Thin Layer Chromatography examination}

The three fractions were spotted on a silica gel GF-254nm TLC plate in duplicates and were developed with a mixture butanol, acetic acid and distilled water at a ratio of $4: 1: 2$, as the mobile phase. The plates were allowed to air-dry after development. They were observed in daylight, under UV lamp at $\lambda 254 \mathrm{~nm}$ and $\lambda 365 \mathrm{~nm}$, and iodine chamber and their retardation factor values noted. a ratio of $1: 1(\mathrm{v} / \mathrm{v})$ and each allowed to stand in the dark for about 30minutes. A solution devoid of the test extracts but containing $2 \mathrm{ml}$ of the DPPH solution and 2 $\mathrm{ml}$ of methanol was used as a negative control while ascorbic acid was used as a reference antioxidant agent for comparison. The absorbances were measured at 517 $\mathrm{nm}$ the percentage inhibition of the concentrations calculated using the formula as shown below.

Table-1: TLC profile of the three chromatography fractions from the n-butanol fraction

\begin{tabular}{|l|l|l|l|}
\hline $\begin{array}{l}\text { Chromatography } \\
\text { Fraction }\end{array}$ & No. of component observed & Observed retardation factor & Mobile phase used \\
\hline A & 4 & $0.23,0.41,0.51,0.58$ & BAW \\
\hline B & 2 & $0.46,0.63$ & BAW \\
\hline C & 2 & $0.44,0.62$ & BAW \\
\hline
\end{tabular}

KEY: BAW $\rightarrow$-butanol: acetic acid: water at a ratio of $(4: 1: 2 v / v / v)$ 


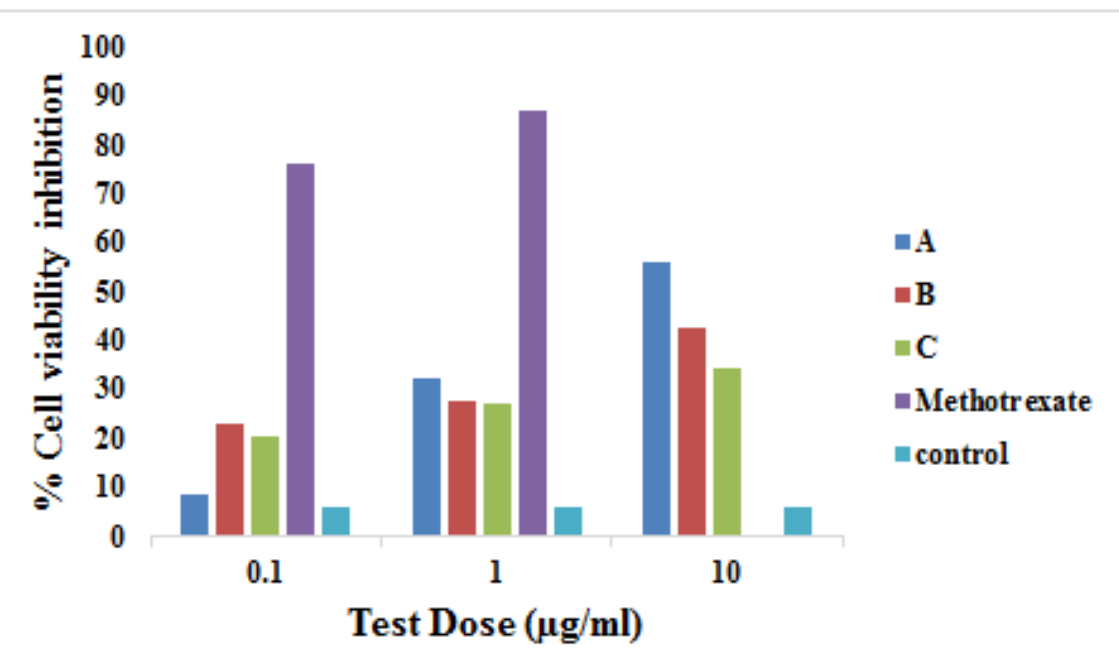

Fig-1: Percentage cell viability inhibition of S. cerevisae when treated with fractions A, B, C, methotrexate and negative control at different concentrations

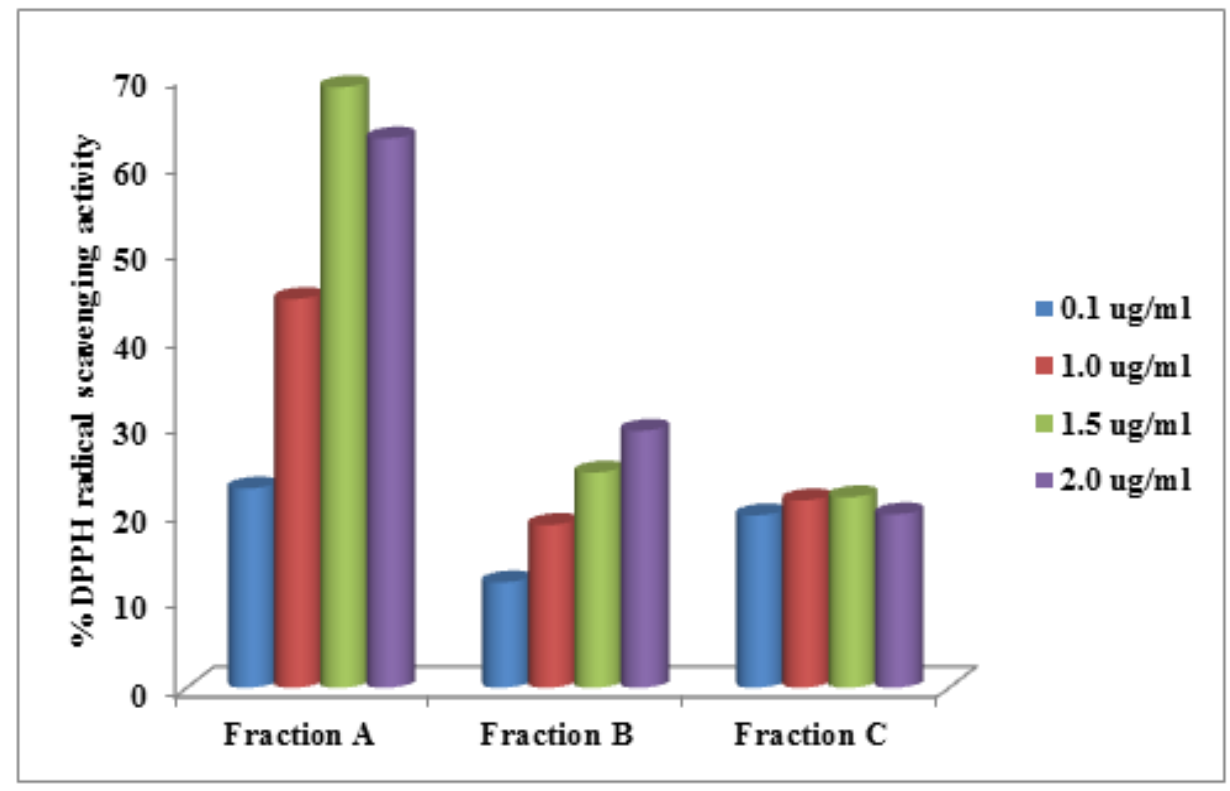

Fig-2: Free radical scavenging activity of chromatography fraction $\mathrm{A}, \mathrm{B}$ and $\mathrm{C}$

The chromatography sub-fraction A showed four distinct constituents with $\mathrm{R}_{\mathrm{f}}$ values $0.23,0.41,0.51$ and 0.58 , while fraction $\mathrm{B}$ and $\mathrm{C}$ showed two components each with $\mathrm{R}_{\mathrm{f}}$ values $(0.46$ and 0.63$)$ and (0.44 and 0.62) respectively under UV light (see Table 1).

The Anti Proliferative (AP) activity was determined by cell viability method using Saccharomyces cerevisae (yeast) as a model organism. The anti-proliferative activities which were expressed in terms of percentage inhibition of viable cell population (Fig. 1) showed a dose dependent reduction in the population of the yeast for each of the subfractions. From the study, chromatography sub-fraction A had a better AP activity than others. Although at a lower dose of $0.1 \mathrm{mg} / \mathrm{ml}$, the percentage inhibition viable cells of sub-fraction $A$ was low as shown in the trend of percentage cell non-viability: A $(8.4 \%)<\mathrm{C}$
$(20.3 \%)<\mathrm{B}(23.1 \%)$, but at a higher concentration of 10 $\mathrm{mg} / \mathrm{ml}$, it showed a significant higher activity: A $(56.8 \%)>\mathrm{B}(42.5 \%)>\mathrm{C}(34.3 \%)$. The standard drug (methotrexate) showed a higher percentage of cell death when compared with the chromatography sub-fractions (Figure 1). The antioxidant activities of the three chromatography sub-fractions were studied by measuring their ability to scavenge DPPH free radicals which was compared with the standard, ascorbic acid. The result of the free radical scavenging activity in Figure 2 showed the $\%$ inhibition of the three chromatography sub-fractions at various concentrations. At a $1.5 \mathrm{mg} / \mathrm{ml}$, chromatography sub-fractions A showed a higher activity than other chromatography sub-fraction: A $(68.8 \%)$ >B (24.6\%) >C (21.8\%). Although all exhibited a less activity when compared with the standard, chromatography sub-fraction $\mathrm{A}$ has a promising result with $\mathrm{IC}_{50}$ of $1.16 \mathrm{mg} / \mathrm{ml}$ while that of standard is $0.012 \mathrm{mg} / \mathrm{ml}$. The above observation has 
shown that chromatography sub-fraction A has a better antiproliferative activity and proton donating ability than chromatography sub-fractions B and C as well and could possibly serve as primary antioxidant. The direct correlation of antioxidant and antiproliferative activities of medicinal plant extracts has been reported [17]. The importance of AP and antioxidant activities in investigation and screening of molecules that can serve as a good lead or drugs for immune related diseases such as cancer, arthritis among others can not be overemphasized [18]. And these sub-fractions have been shown by the phytochemical results to be saponinrich-fractions. It can be concluded that the antioxidant and antiproliferative activity of these sub-fractions is due to the presence of saponin. Saponin is a diverse group of compounds that are widely distributed in the plant kingdom which are usually characterized by their structure containing a steroidal or triterpenoid aglycone and one or more sugar chains [19] that demonstrate various pharmacological effects against mammalian diseases. Research has shown that a lot of saponins have anticancer activity and displays their effects through various antitumor pathways. A saponin, saikosaponin have been reported to exert its anticancer effect by antiproliferative activity [9]. saponins have also been shown to reduce the effects of radiotherapy and chemotherapy [20].

\section{CONCLUSION}

Olax viridis contains many phyto-constituents that possess the potential of proffering solution to man's health challenges. The butanol portion of the methanolic extract of the root bark of $O$. viridis is rich in saponin, and its sub-fractions exhibited a dose dependent anti-proliferative activity. Although all subfractions have the same class of phyto-consistuent, subfraction A showed a better anti-proliferative and antioxidant activity. This preliminary study also validated the traditional use of Olax species in the treatment of cancer. This sub-fraction could be a candidate for new anticancer drugs.

\section{REFERENCES}

1. WHO. (2018). Cancer. In: https://www.who.int/news-room/factsheets/detail/cancer. Reterived on April 9, 2020

2. Jemal , A., Bray, F., Forman, D., O'Brien, M., Ferlay, J., Center, M., \& Parkin, D.M. (2012). Cancer burden in Africa and opportunities for prevention. Cancer. 118(18):4372-84

3. Iwu, M. W., Duncan, A.R., \& Okunji, C. O. (1999). New antimalarials of plant origin. In: Janick J (ed.). Perspective on new crops and new uses. Alexandria, 457-462

4. Sowofora, E. A. (2006). Medicinal plants and traditional medicine in Africa. Spectrum book Ltd, Ibadan, Nigeria, 134-155.

5. Gbadamosi, I. T., \& Erinoso, S. M. (2015). A review of twenty ethnobotanicals used in the management of breast cancer in Abeokuta, Ogun
State, Nigeria. African Journal of Pharmacy and Pharmacology, 10(27), 546-564.

6. Ashidi, J. S., Houghton, P. J., Hylands, P. J., \& Efferth, T. (2010). Ethnobotanical survey and cytotoxicity testing of plants of South-western Nigeria used to treat cancer, with isolation of cytotoxic constituents form Cajanus cajan Millsp. Leaves. Journal of Ethnopharmacology, 128(2):501-512.

7. Kolanjiappan, K., \& Manoharan, S. (2005). Chemopreventive efficacy and anti-lipid peroxidative potential of Jasminum grandiflorum Linn. Fundamental and Clinical Pharmacology, 19(6), 687-693.

8. Pandey, G., \& Madhuri, S. (2009). Some medicinal plants as anticancer agents. Pharmacognosy Review, 3, 259-263.

9. Chen, M.F., Huang, S.J., Huang, C.C., Liu, P.S., Lin, K.I, Liu, C.W., Hsieh W.C, Shiu L.Y \& Chen C.H. (2016). Saikosaponin D induces cell death through caspase-3-dependent, caspase-3independent and mitochondrial pathways in mammalian hepatic stellate cells. BMC Cancer, 16: 532.

10. Bachran, C., Bachran, S., Sutherland, M., Bachran, D., \& Fuchs, H. (2008). Saponins in tumor therapy. Mini reviews Medicinal Chemistry, 8(6), 575-584.

11. Harbourne, J.B. (1973). Phytochemical methods. Chapman and Hall Ltd., London, 49-188.

12. Houghton, PJ, Raman, A. (1999). Laboratory Handbook for the Fractionation of Natural Extracts. London: Chapman and Hall;

13. Madea, F., \& Emgelhardt, S. (2002). Apoptosis in yeast: a new model system with applications in cell biology and medicine. Current. Genetic, 41(4): 208-216.

14. Brand-Williams, W., Cuvelier, M.E., \& Berset, C. (1995). Use of a free radical method to evaluate antioxidant activity. Lebensm-Wiss u-Technol; 28: 25-30.

15. Molyneux, P. (2004). The use of the stable free radical diphenylpicrylhydrazyl (DPPH) for estimating antioxydant activity. Songklanakarin Journal of Science and Technology, 26(2):211219.

16. Okonkwo, T.J. N., \& Elechi, N. A. (2011). Phytochemical and antimicrobial studies of Olaxviridis OLIV. (olacaceae) fruit. J. pharm and Allied Sci., 8(3), 1371-1378.

17. Okonkwo, B.O., Afieroho, O.E., Ahanonu, E.D., Okwubie, L., \& Abo, K.A. (2019). Pleurotus pulmonarius (Fr.) Quel. (Pleurotaceae): In vitro anti-oxidant evaluation and the isolation of a steroidal isoprenoid. Journal of Applied Biology and Biotechnology, 7(04): 32-38.

18. Qaddouri, B., Guaadaoui, A., Bellirou, A., Hamal, A., Brown, G. W., \& Bellaoui, M. (2011). The budding yeast 'Saccharomyces cerevisiae' as a drug discovery tool to identify plant-derived natural products with antiproliferative properties. 
Evidence based complementary alternative medicine, 2011, 954140.

19. Kensil, C. R. (1996). Saponins as vaccine adjuvants. Critical Review Therapeutic Drug Carrier systems, 13(1-2), 1-55.

20. Zhao, P. J., Song, S. C., Du, L. W., Zhou, G. H., Ma, S. L., Li, J. H., Feng JG, Zhu XH, Jiang H.
(2016). Saponin enhances radiosensitivity in a gefitinib-resistant lung adenocarcinorma cell line by inducing apoptosis and G2IM cell cycle phase arrest. Molecular Medicine Reports, 13(3): 28782884. 